\title{
Curva de sobrevivência de bactérias isoladas do leite de vacas com mastite a três extratos etanólicos de própolis*
}

\section{Time kill curve of bacteria isolated from milk of cows with mastitis to three ethanolic extracts of propolis}

\author{
Marcelo Souza Pinto, ${ }^{\star \star}$ José Eurico de Faria, ${ }^{\star \star \star}$ Sérvio Túlio.Alves Cassini, ${ }^{\star \star \star \star}$ Dejair Message, ${ }^{\star \star \star \star \star}$
}

Carmen Silva Pereira* ${ }^{\star \star \star \star \star}$

\begin{abstract}
Resumo
Estudou-se o efeito de extratos etanólicos de própolis obtidos por álcool 70, 80 e 95\%, sobre amostras de Staphylococcus aureus e Streptococcus agalactiae isoladas do leite de vacas com maștite. Não houve diferença significativa $(p>0,01)$ na atividade antibacteriana entre os três tipos de extratos etanólicos de própolis estudados. As duas concentrações de extratos etanólicos utilizadas na avaliação da sensibilidade do Staphylococcus aureus, 3,0 e 2,0 mg/mL, inibiram, de maneira semeIhante, as três amostras bacterianas testadas. Somente em uma amostra foi observada ação bactericida dos extratos etanólicos de própolis, em ambas as concentrações, a partir de 12 horas de exposição. Nas duas amostras de Streptococcus agalactiae, observou-se o efeito bactericida da própolis ao final do período de 24 horas de exposição às concentrações de 0,43 e $0,3 \mathrm{mg} /$ $\mathrm{mL}$. Verificou-se que, com dosagens cerca de dez vezes menores que as aplicadas para Staphylococcus aureus, houve uma completa e irreversível inibição do Streptococcus agalactiae, dentro do período estudado. Estes resultados estimulam o prosseguimento de novas investigações sobre a utilização de extratos de própolis, em veículos adequados, com vistas ao tratamento da mastite bovina.
\end{abstract}

Palavras-chave: própolis, antibacteriano, mastite, Staphylococcus aureus, Streptococcus agalactiae.

\begin{abstract}
This study shows the effect of ethanolic extracts of propolis obtained by 70,80 and $95 \%$ of ethanol on Staphylococcus aureus and Streptococcus agalactiae strains, isolated from milk of cows with mastitis. There were no significant differences $(P>0.01)$ in the antibacterial activity among the three types of ethanolic extracts of propolis. The two concentrations of ethanolic extracts utilized in the sensitivity test of the Staphylococcus aureus, 3.0 and $2.0 \mathrm{mg} / \mathrm{mL}$, were similar in the inhibition of the three strains tested. The bactericidal action of the ethanolic extracts of propolis was observed in only one strain, in both concentrations, from 12 hours of exposure. In the two strains of Streptococcus agalactiae, the bactericidal effect of propolis was observed at the end of 24 hours of exposure to 0.43 and $0.3 \mathrm{mg} / \mathrm{mL}$ concentrations. Dosages at least ten times smaller than those applied to Staphylococcus aureus caused a complete and irreversible inhibition of the Streptococcus agalactiae, during the studied period. These results stimulate further investigations on the use of propolis extracts, using appropriate vehicles in bovine mastitis treatment.
\end{abstract}

Keywords: propolis, antibacterial, mastitis, Staphylococcus aureus, Streptococcus agalactiae.

\section{Introdução}

A mastite é considerada a principal doença que afeta os rebanhos leiteiros no Brasil e em todo o mundo e aquela que proporciona as maiores perdas econômicas na exploração de bovinos leiteiros. Estima-se que, mundialmente, as perdas anuais causadas pela doença sejam por volta de $35 \mathrm{bi}$ -
Ihões de dólares (Giraudo et al., 1997). A diminuição na produção de leite é responsável pela maior parcela do total das perdas, visto que há uma diminuição substancial na produção em vacas infectadas. Incluem-se, ainda, gastos com medicamentos, leite descartado, serviços veterinários, descarte prematuro de animais, diminuição no valor comercial dos animais infectados e interferência no desenvolvimento

\footnotetext{
* Apoio Financeiro: FAPEMIG

** Médico-veterinário, Mestre em Medicina Veterinária, Universidade Federal de Viçosa.

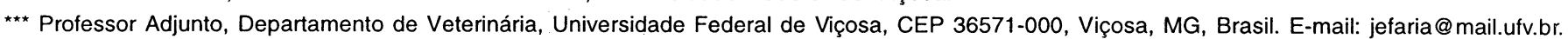
Autor para correspondência.

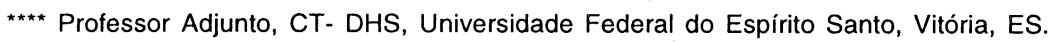

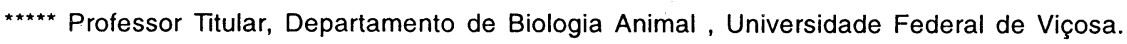

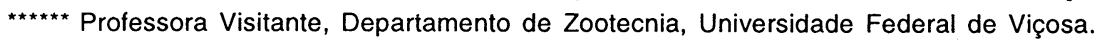


genético de raças leiteiras (Degraves e Fetrow, 1993; National Mastitis Council, 1998). Deve-se considerar, também, as perdas ocasionadas à indústria de laticínios, devido à queda na qualidade do produto em função das alterações na sua composição química (Degraves e Fetrow, 1993).

Nos últimos anos, houve um crescente interesse na utilização de medicamentos de origem natural, obrigando a ciência a se esforçar cada vez mais na busca do desenvolvimento de novas drogas, sempre objetivando adquirir maior eficiência e menor toxicidade. Nesse sentido, os produtos apícolas ganham mais espaço neste contexto e, dentre eles, a própolis, através de seu variado número de atividades biológicas descritas. Muitos trabalhos nacionais e estrangeiros ilustram a diversidade de atividades biológicas da própolis e, dentre elas, a antibacteriana. A grande maioria dos relatos mostra que os diversos tipos de extratos de própolis possuem acentuada ação inibidora, in vitro, sobre gêneros Gram-positivos e, em menor escala, sobre as bactérias Gram-negativas (Grange e Davey, 1990; Kujumgiev et al., 1999). As reconhecidas capacidades antiinflamatória e imunomodulatória da própolis (Dobrowolski et al., 1991; Miyataka et al., 1998) também servem de estímulo para as investigações acerca de sua utilização em processos inflamatórios, como a mastite, em bovinos.

A própolis se constitui numa série de substâncias resinosas, gomosas e balsâmicas, de consistência viscosa, recolhida de certas partes dos vegetais, como brotos e cascas de árvores ou de outras partes do tecido vegetal, pelas abelhas, que a transportam até a colmeia, onde adicionam e modificam sua composição, através de secreções próprias como a cera e secreções salivares essenciais ou, ainda, seria resultante do processo de digestão do pólen pelas abelhas (Ghisalberti, 1979). Possui como descrição física e características sensoriais: aroma característico (balsâmico e resinoso), dependendo da origem botânica, cor variável desde a amarelada, parda, esverdeada clara ao pardo escuro, sabor de suave balsâmico a forte, amargo e picante e consistência maleável à ligeiramente rígida, à temperatura ambiente, e rígida em temperaturas abaixo de $20^{\circ} \mathrm{C}$ (APACAME, 1999). É composta, em média, por $55 \%$ de resinas e bálsamos, $30 \%$ de ceras, $10 \%$ de óleos voláteis e $5 \%$ de pólen (Ghisalberti, 1979; Bonvehi et al., 1994).

Possui uma composição química complexa, contendo mais de 160 componentes e, dentre os compostos químicos identificados, podem ser citados os flavonóides (flavonas, flavolonas e flavononas), chalconas, ácido benzóico e derivados, benzaldeídos, alcoóis, cetonas, fenólicos, heteroaromáticos, álcool cinâmico e derivados, ácido caféico e derivados, ácidos diterpenos e triterpenos, minerais e outros (Walker e Crane, 1987; Bonvehi et al., 1994; Marcucci, 1995; Bankova et al., 1998; Seixas et al., 2000).

Dependendo do tipo de solvente empregado na extração ou mesmo das condições utilizadas no processo, haverá maior ou menor eficiência de extração das substâncias fenólicas, nas quais concentra-se a maior parte da atividade farmacológica da própolis (Marcucci et al., 1999). O uso de álcool hidratado a $70 \%$ na extração da própolis resulta em extratos com maior conteúdo de substâncias fenólicas que no caso de extração com álcool absoluto, embora não tenha sido notado diferença na produção de flavonóides entre os dois tipos de solventes. O álcool absoluto extrai parte da cera, enquanto a extração pela solução hidroalcoólica a $70 \%$ resulta numa tintura livre de cera (Woisky e Salatino, 1998).

A própolis e alguns de seus componentes possuem efeitos sobre a permeabilidade da membrana interna bacteriana aos íons, causando a dissipação do potencial de membrana. Como o gradiente eletroquímico de prótons através da membrana é essencial para a bactéria, por manter a síntese de ATP, o transporte através da membrana plasmática e a motilidade, tal efeito pode, conseqüentemente, contribuir muito sobre toda a ação citotóxica da própolis, podendo ainda diminuir a resistência das células a outros compostos antibacterianos (Mirzoeva et al., 1997). Este fato pode explicar a ação sinérgica entre própolis e alguns antibióticos

Takaisi-Kikuni e Schilcher (1994) observaram, através da microscopia eletrônica, que o Extrato Etanólico de Própolis (EEP), em Streptococcus agalactiae, inibe o crescimento bacteriano por prevenir a divisão celular, levando à formação de estreptococos pseudomulticelulares (policarióticos), desorganiza o citoplasma, caracterizado pela presença de espaços vazios ou estruturas fibrosas (fibrous-like), e ainda causa alteração na membrana citoplasmática e defeitos na estrutura da parede celular, levando à bacteriólise parcial. Os mesmos autores, através de técnicas de microcalorimetria, ainda constataram que o EEP inibe a sintese protéica.

Testes realizados com amostras referência de Staphylococcus aureus (ATCC 25923) e Escherichia coli (ATCC35218), quando submetidas a diferentes concentrações de Extrato Etanólico de Própolis (EEP) a $50 \% \mathrm{v} / \mathrm{v}$, mostraram que concentrações de EEP aproximadamente iguais ou maiores que as respectivas Concentrações Mínimas Inibitórias (CMI) exercem efeito bactericida marcante a partir de seis a nove horas de exposição. Embora os perfis da curva do tempo de sobrevivência das duas bactérias estudadas tenham sido similares, a concentração do EEP para exercer efeito bactericida efetivo sobre a E.coli foi cerca de 10 vezes maior que o observado para o S. aureus (Fernandes Júnior et al., 1997).

Glinski e Meresta (1993) estudaram a ação antimicrobiana de 592 amostras de própolis de várias regiões da Polônia e mostraram que seus extratos etanólicos diferiram nas suas atividades antimicrobianas. A Concentração Mínima Inibitória (CMI) dos extratos variou de 0,06 a $0,49 \mathrm{mg} / \mathrm{mL}$ e a Concentração Mínima Bactericida (CMB), de 0,11 a 1,68 mg/mL para Staphylococcus aureus. Assim, os autores sugerem que a padronização da própolis deve ser baseada tanto nos valores de $\mathrm{CMI}$ quanto na $\mathrm{CMB}$. Ainda sugerem que a própolis mais efetiva deve ser caracterizada por valores de CMI abaixo de $0,3 \mathrm{mg} / \mathrm{mL}$ e CMB não mais que $0,45 \mathrm{mg} / \mathrm{mL}$ e que os métodos de extração e de determinação da atividade antibacteriana devem ser rigidamente definidos, pois afetam tanto a CMI quanto a CMB da própolis.

Estudos in vitro da eficácia antimicrobiana de extrato alcoólico de própolis, proveniente de apiários em Botucatu, SP, mostraram $100 \%$ de inibição do crescimento de estirpes de Staphylococcus aureus e Corynebacterium bovis e, respectivamente, $90 \%$ e $91 \%$ de inibição das estirpes de Streptococcus agalactiae e Escherichia coli, testadas (Langoni et al., 1994). Deve-se ressaltar que essas espécies bacterianas estão entre as mais importantes e prevalentes na etiologia da mastite bovina. 
Existem poucos trabalhos na literatura científica sobre o uso de extratos de própolis e/ou derivados no tratamento ou prevenção da mastite em bovinos ou em outra espécie doméstica. O primeiro relato na literatura sobre a utilização de um protocolo de tratamento de mastite através da própolis remonta a 1980, por Mirolyubov e Barskov (1980).

Meresta et al. (1989) testaram um tratamento de mastite bovina com extrato de própolis. A recuperação completa foi observada em $86,6 \%$ das vacas com mastite aguda, em $100 \%$ dos casos de infecção causados por Candida albicans, $85 \%$ por Escherichia coli, $91 \%$ por Staphylococcus sp e $84,3 \%$ por Streptococcus sp. Os autores ainda concluíram que a própolis apresenta-se bastante efetiva na terapia da mastite causada por microrganismos resistentes aos antibióticos convencionais.

\section{Material e métodos}

Após diagnosticada a mastite, em suas diversas formas de apresentação, as amostras de leite para isolamento e identificação do agente foram colhidas, imediatamente antes da ordenha, em frascos esterilizados, com os devidos cuidados de higiene e assepsia, conforme Faria (1995).

As amostras de leite foram inicialmente pré-incubadas a $37^{\circ} \mathrm{C}$, por seis a 18 horas e, posteriormente, inoculadas em placas contendo ágar sangue base, adicionado de $5 \%$ de sangue desfibrinado de carneiro e então incubadas a $37^{\circ} \mathrm{C}$, por $24-48$ horas (National Mastitis Council, 1969).

Unidades Formadoras de Colônias (UFC) com características macroscópicas próprias de estafilococos, estreptococos foram transferidas para tubos contendo caldo cérebro coração de bezerro ("BHI") e incubadas a $37^{\circ} \mathrm{C}$, por 24 horas. Para a identificação das espécies bacterianas, além das características morfotintoriais pelo método de Gram, utilizou-se o método recomendado pelo "National Mastitis Council" (1969). Também foram empregados testes específicos para identificação de cada espécie.

A classificação presuntiva do Staphylococcus aureus se baseou nas seguintes provas, as quais apresentaram resultados positivos: Hemólise em ágar sangue; Prova da Catalase (Holmberg, 1973); Prova da coagulase (Schalm et al., 1971); Reação da desoxirribonuclease (DNase) (Kowalski, 1977), em ágar DNase; Fermentação do manitol, em ágar salmanitol; Crescimento anaeróbio em meio líquido de tioglicolato de Brewer (Evans e Kloos, 1972); Reação de Voges-Proskawer, conforme descrito em Bier (1985).

Os estreptococos foram identificados de acordo com a Prova da Catalase (Holmberg, 1973), Reação de CAMP (Quinn et al., 1994) e tipo de hemólise em ágar sangue de carneiro (Quinn et al., 1994).

A própolis estudada foi produzida pelo sistema CPI ${ }^{\circledast}$ (Coletor de Própolis Inteligente), desenvolvido pelo apicultor Sr. Adomar Jesus de Carvalho. Foi colhida em colmeias de abelhas africanizadas, Apis mellifera, numa propriedade rural localizada no Município de Itapecerica (MG), e cedida pelo referido apicultor. A própolis possuía cor verde e odor balsâmico agradável.

Os fragmentos da placa de própolis foram triturados, pesados e, posteriormente, secados, dentro de uma placa de Petri, em estufa a $50^{\circ} \mathrm{C}$, por 18 horas. Na preparação dos extratos adicionaram-se três concentrações diferentes de álcool etílico $(70,80$ e $95 \%)$ na proporção de $3 \mathrm{~g}$ de própolis pura para cada $10 \mathrm{~mL}$ de solvente. Logo a seguir, as soluções foram colocadas em estufa a $45^{\circ} \mathrm{C}$, sob agitação, por 48 horas è, finalmente, filtradas em papel de filtro WhatmanÒ número 1. Classificaram-se os filtrados como sendo Extrato Etanólico 70\% (EEP 70), Extrato Etanólico 80\% (EEP 80) e Extrato Etanólico 95\% (EEP 95). Foi efetuada a medição da resina obtida no processo de extração e então prepararam-se soluções estoque numa concentração de $300 \mathrm{mg} / \mathrm{mL}$ do respectivo solvente (etanol 70, 80 e 95\%).

As concentrações de extratos de própolis (EEP-70, EEP-80 e EEP-95), em caldo "BHI", utilizadas para a análise, foram encontradas a partir de resultados obtidos em testes preliminares. Assim, foram aplicadas as seguintes doses: 2,0 e 3,0 $\mathrm{mg} / \mathrm{mL}$ para o $S$. aureus e 0,3 e $0,43 \mathrm{mg} / \mathrm{mL}$ para o $S$. agalactiae. Nestes mesmos testes pilotos verificou-se que, somente em concentrações acima de $60 \mathrm{mg} / \mathrm{mL}$, os solventes começavam a exercer efeito bactericida.

A determinação do número de Unidades Formadoras de Colônias por mililitro (UFC/mL) foi obtida em placas contendo meio Plate Count Agar (PCA). Com a finalidade de se estudar o efeito das diferentes concentrações dos extratos etanólicos da própolis e do tempo de exposição das bactérias a esses extratos, a inoculação das alíquotas de "BHI" $(0,1 \mathrm{~mL})$ em meio PCA foi realizada após 0, 6, 12 e 24 horas de incubação a $37^{\circ} \mathrm{C}$ em meio "BHI" sem própolis (controle) e "BHI" com própolis. Após a incubação das placas por 24 horas $37^{\circ} \mathrm{C}$, finalmente contavam-se aquelas que continham até 300 UFC.

Os testes foram realizados em triplicata e o experimento foi analisado como do tipo Parcelas Subdivididas (Split Plot), no Delineamento Inteiramente Casualizado, sendo considerado como a subparcela, os quatro momentos de contagem de UFC $/ \mathrm{mL}$. Todas as análises estatísticas foram realizadas no Software SAEG/UFV, versão 5.0.

\section{Resultados e discussão}

Foi verificado que os solventes não exerciam efeito inibidor ou bactericida sobre as culturas bacterianas de Staphylococcus aureus e Streptococcus agalactiae, incubadas a $37^{\circ} \mathrm{C} / 24$ horas, quando aplicados nos tubos de "BHI" nas mesmas quantidades utilizadas para os extratos.

Não houve diferença estatística significativa $(p>0,01)$ na atividade antibacteriana dos extratos de própolis extraídos pelas diferentes concentrações de álcool etílico hidratado, demonstrando que os três extratos tiveram comportamentos semeIhantes na atividade antimicrobiana sobre as bactérias testadas. Este dado, de certo modo, discorda de autores que relatam diferenças entre extratos etanólicos de própolis produzidos a partir de alcoóis diferenciados. Segundo Marcucci et al. (1999), há maior ou menor eficiência de extração das substâncias fenólicas, nas quais se concentra a maior parte da atividade farmacológica da própolis, dependendo do tipo de solvente empregado na extração ou mesmo das condições utilizadas no processo. Park et al. (1998) observaram que a maioria dos flavonóides identificados (quercetina, acacetina, kanferide, isoramnectina, pinocembrina) foram extraídos nas porcentagens etanólicas entre 60 e $80 \%$. Por conseqüência, a maior porcentagem de inibição do crescimento microbiano foi proporcionado pelos extratos etanólicos de própolis por 
álcool 60, 70 e $80 \%$, havendo um decréscimo nesta atividade nas porcentagens mais altas de etanol (90 e 95\%).

Acreditava-se que o uso de diferentes alcoóis pudesse produzir extratos etanólicos com algumas diferenças na composição química e, portanto, com atividades antimicrobianas um pouco diferenciadas. Como não houve esta distinção de atividade biológica entre os três extratos, possivelmente os componentes responsáveis por tal propriedade estavam presentes nas três soluções. Woisky e Salatino (1998) verificaram extratos com maior conteúdo de substâncias fenólicas quando utilizaram álcool hidratado a $70 \%$ na extração da própolis que, no caso de extração por álcool absoluto, embora não tenha sido notada diferença na produção de flavonóides entre os dois tipos de solventes. Obregon e Rojas (1990) verificaram que os resultados das análises de susceptibilidade bacteriana a diferentes extratos alcoólicos de própolis variavam com o método de extração aplicado, porém independentemente da concentração de álcool utilizada.

Pôde-se constatar, também, diferenças significativas $(p<0,01)$ entre os números de UFC/mL, em todas as cinco amostras bacterianas, quando analisados os fatores concentração do extrato etanólico da própolis, tempo de incubação das amostras e a interação entre estes dois fatores.

As figuras 1, 2, 3, 4 e 5 ilustram os perfis das curvas de sobrevivência das bactérias $S$. aureus amostra Viçosa I, $S$ aureus amostra Teixeiras II, $S$. aureus amostra Teixeiras III, $S$. agalactiae amostra UFV II e $S$. agalactiae amostra ES-ST I, respectivamente, a duas concentrações de EEP por amostra bacteriana. Como não houve diferença entre os extratos, as médias estudadas nesta análise foram obtidas a partir do conjunto dos três extratos, EEP-70, EEP-80 e EEP-95.

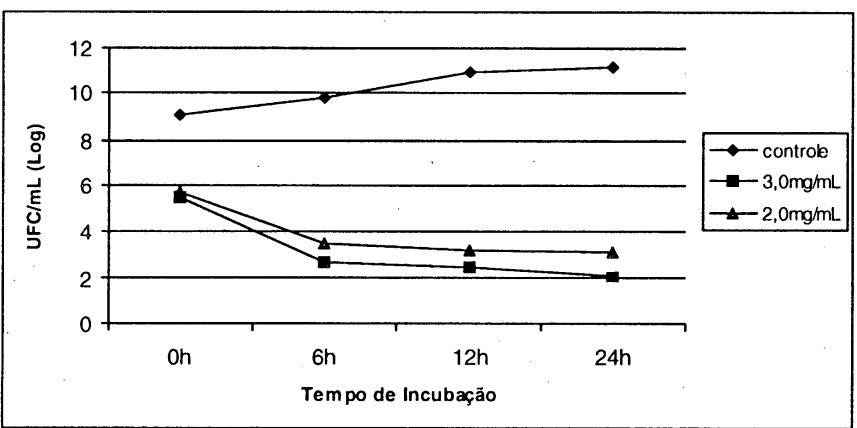

Figura 1 - Perfil da curva de sobrevivência do Staphylococcus aureus, amostra Viçosa I, aos extratos etanólicos de própolis

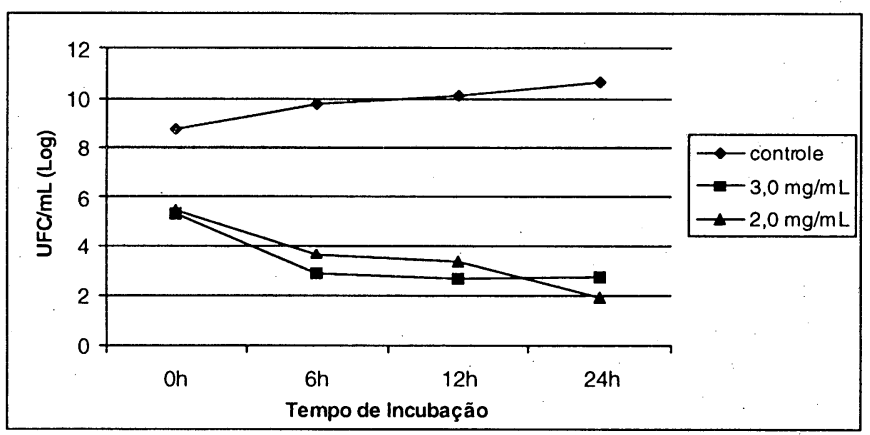

Figura 2 - Perfil da curva de sobrevivência do Staphylococcus aureus, amostra Teixeiras II, aos extratos etanólicos de própolis

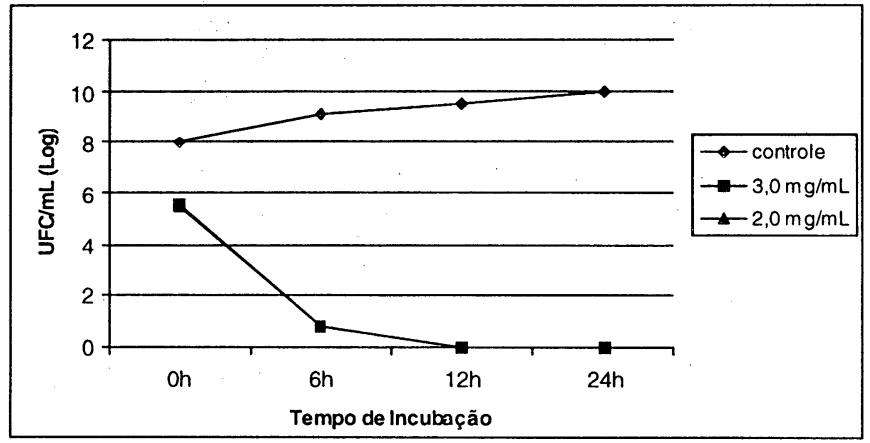

Figura 3 - Perfil da curva de sobrevivência do Staphylococcus aureus, amostra Teixeiras III, aos extratos etanólicos de própolis

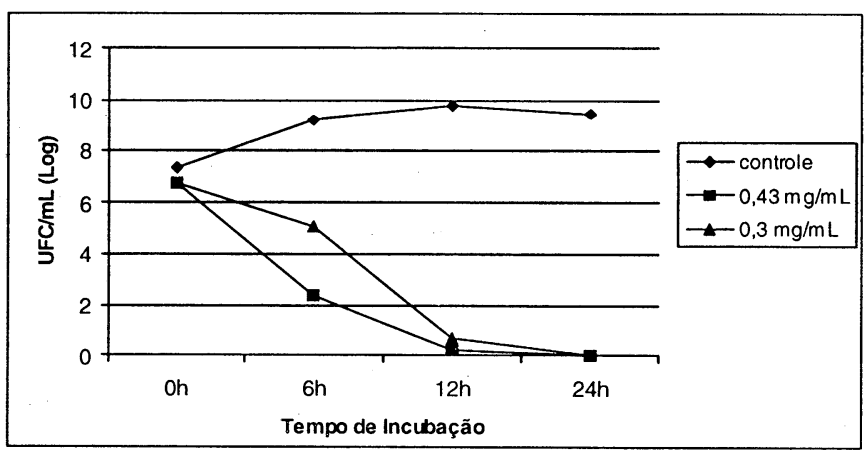

Figura 4 - Perfil da curva de sobrevivência do Streptococcus agalactiae, amostra UFV II, aos extratos etanólicos de própolis

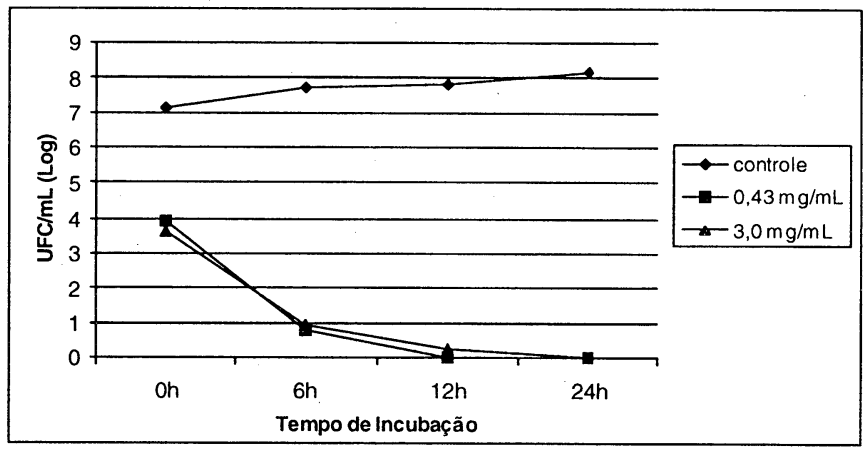

Figura 5 - Perfil da curva de sobrevivência do Streptococcus agalactiae, amostra ES-ST I, aos extratos etanólicos de própolis

Observa-se que, nas três amostras de Staphylococcus aureus estudadas, houve uma inibição do crescimento bacteriano já a partir do tempo zero (Oh). Enquanto no tubo controle persistia o crescimento bacteriano, nos tubos com as duas concentrações de própolis a inibição foi clara e acentuada durante todo o período de avaliação. Isto pode demonstrar um efeito bactericida da própolis pois, logo num primeiro contato com as células bacterianas, foi visível que a mesma proporcionou uma queda do número de unidades formadoras de colônia.

As duas concentrações utilizadas na avaliação da sensibilidade do $S$. aureus, $3,0 \mathrm{mg} / \mathrm{mL}$ e $2,0 \mathrm{mg} / \mathrm{mL}$, inibiram, de maneira semelhante, as três amostras bacterianas testadas. Somente na amostra Viçosa I, houve diferença entre as duas 
concentrações, ao final das 24 horas de incubação. A dose de $3,0 \mathrm{mg} / \mathrm{mL}$ diminuiu mais o número de $\mathrm{UFC} / \mathrm{mL}$ que a dose de $2,0 \mathrm{mg} / \mathrm{mL}(p<0,05)$.

Durante todo o período de avaliação, não foi observado nenhum indício de reversão do crescimento bacteriano, em qualquer amostra, perante a própolis. $\mathrm{Na}$ amostra $S$. aureus Teixeiras III, constatou-se uma ação bactericida da própolis, em ambas as dosagens, a partir de 12 horas de incubação. Não foi verificada ação bactericida completa dos extratos de própolis nas amostras Viçosa I e Teixeiras II, em nenhuma das concentrações utilizadas, durante o período de 24 horas do estudo. Tal fato indica que há variação na sensibilidade à própolis entre isolados de $S$. aureus de origens diferentes, como comumente acontece com outros tipos de antimicrobianos.

Conforme relatado por diversos autores, o $S$. aureus é sensível a muitos compostos presentes nos mais diversos tipos de extratos de própolis, de diferentes origens. Assim, podese explicar a acentuada sensibilidade deste importante agente infeccioso à própolis pesquisada no presente trabalho.

Segundo Grange e Davey (1990) e Kujumgiev et al. (1999) a ação bactericida da própolis sobre Staphylococcus $s p$, e sobre a grande maioria dos microrganismos sensíveis, seria o resultado de uma ação conjunta de vários componentes, pois nenhum composto isolado possui atividade maior que a do extrato total. Isto sugere que a composição química da própolis possui valor farmacológico geral como uma mistura natural, e não como uma fonte de novos compostos antimicrobianos poderosos.

Também pôde-se verificar uma redução significativa no número de unidades formadoras de colônias a partir de seis horas de incubação, resultado este semelhante aos verificados por Fernandes Jr. et al. (1997), que encontraram, sobre o $S$. aureus, um efeito inibidor marcante a partir de seis a nove horas de exposição ao extrato etanólico de própolis.

Embora tenham sido observados efeitos inibidor e bactericida completa ou não, dos extratos de própolis para isolados de $S$. aureus, a dosagem requerida para tanto, neste experimento, foi muito acima das encontradas pela maioria dos autores. Enquanto, neste estudo, utilizaram-se dosagens de 2 e $3 \mathrm{mg} /$ $\mathrm{mL}$ para se obter efeito inibidor, bactericida e bactericida completa (esta última no caso da amostra $S$. aureus Teixeiras III), Glinski e Meresta (1993) e Bonvehi et al. (1994) encontraram valores que variaram de 0,06 a $1,68 \mathrm{mg} / \mathrm{mL}$ e de 0,08 a 0,1 $\mathrm{mg} / \mathrm{mL}$, respectivamente. No caso de amostras de Staphylococcus aureus isoladas de casos de mastite bovina, Meresta e Meresta (1985), encontraram uma concentração mínima inibitória em torno de $80 \mathrm{mg} / \mathrm{mL}$. Estas diferenças possivelmente estão relacionadas às composições químicas diferentes da amostra de própolis e à sensibilidade dos isolados de $S$. aureus estudados. Os autores citados utilizaram própolis de origem européia. É necessário esclarecer ainda, que processos de extração diferenciados podem influenciar decisivamente na composição química de um extrato e, assim, nas suas atividades biológicas.

Observam-se que nas duas amostras de Streptococcus agalactiae estudadas, assim como nas amostras de $S$. aureus, houve uma inibição do crescimento bacteriano já a partir do tempo zero (Oh), embora esta redução não tenha sido estatisticamente significativa $(p>0,05)$ no tempo zero, para o $S$. agalactiae amostra UFV II. Enquanto no tubo controle havia ainda o crescimento bacteriano, nos tubos com as duas concentrações de própolis, a inibição foi clara e acentuada durante todo o período de avaliação.

Nas duas amostras bacterianas houve efeito bactericida completo da própolis ao final do período de 24 horas de exposição. Com seis horas de incubação, observou-se diferença estatisticamente significativa $(p<0,05)$ no número de $U F C / m L$ entre as duas concentrações adotadas $(0,43$ e $0,3 \mathrm{mg} / \mathrm{mL}$ ) $\mathrm{Na}$ amostra $S$. agalactiae UFV II, a concentração de $0,43 \mathrm{mg} /$ $\mathrm{mL}$, até então, inibiu mais o crescimento bacteriano, se comparado à concentração de $0,3 \mathrm{mg} / \mathrm{mL}$. Mas, ao final de 24 horas, as duas concentrações conseguiram levar o número de UFC/mL a zero.

$\mathrm{Na}$ amostra S. agalactiae ES-ST I, o comportamento das duas concentrações foi semelhante, não havendo diferença entre elas em nenhum momento da análise. Ambas produziram efeito bactericida completo ao final das 24 horas de incubação.

Assim como observado nas amostras de $S$. aureus, estes resultados mostram que também há variação na sensibilidade à própolis de amostras de $S$. agalactiae de origens diferentes, como comumente acontece com outros tipos de antimicrobianos.

Pode-se observar que, com dosagens cerca de dez vezes menores que as aplicadas para $S$. aureus, houve uma completa e irreversível inibição do $S$. agalactiae, dentro do período estudado, demonstrando mais uma vez que este agente infeccioso se mostra muito sensível à própolis.

Segundo Takaisi-Kikuni e Schilcher (1994), o extrato etanólico de própolis inibe o crescimento de Streptococcus agalactiae por ter a capacidade de prevenir a divisão celular, levando à formação de estreptococos pseudomulticelulares (policarióticos), inibir a síntese protéica, desorganizar o citoplasma, caracterizado pela presença de espaços vazios ou estruturas fibrosas (fibrous-like) e, ainda, causar alteração na membrana citoplasmática e defeitos na estrutura da parede celular, levando à bacteriólise parcial. Possivelmente, estes mecanismos de injúria à célula bacteriana foram os responsáveis pela ação bactericida verificada no presente estudo. Assim como encontrado neste trabalho, os autores também verificaram diferenças na sensibilidade bacteriana ao EEP entre as duas amostras de Streptococcus agalactiae que estudaram, porém, encontraram uma concentração mínima inibitória do EEP $(25 \% \mathrm{v} / \mathrm{v})$ sobre o Streptococcus agalactiae, entre $5,0 \times$ $10^{-4}$ a $1,5 \times 10^{-3} \mathrm{mg} / \mathrm{mL}$, muito menor do que a estudada neste experimento $(0,43$ e $0,3 \mathrm{mg} / \mathrm{mL})$. Mais uma vez, tal diferença pode ser explicada por fatores que podem alterar decisivamente o resultado de um ensaio biológico em relação ao outro, como: origens diferentes das amostras de própolis estudadas e, por conseqüência, as suas composições químicas, fatores como as diferentes estirpes de bactérias de uma mesma espécie, a concentração e metodologia adotada no processo de extração da própolis e, finalmente, o método de avaliação da inibição do crescimento bacteriano (condições de temperatura, tipos de meios de cultura, tempo de incubação, técnicas diferentes de análise).

Diante dos resultados observados e nas condições em que foi conduzido o presente experimento, pode-se concluir que: Amostras diferentes, de uma mesma espécie bacteriana, di- 
ferem quanto à sensibilidade à própolis. Não se obtiveram diferenças na atividade antibacteriana de extratos etanólicos produzidos através dos alcoóis 70,80 e $95 \%$. As concentrações de 2,0 e $3,0 \mathrm{mg} / \mathrm{mL}$ de extratos etanólicos de própolis

\section{Referências}

Associação Paulista de Apicultores Criadores de Abelhas Melíficas Européias - APACAME. Regulamentos técnicos para fixação de identidade e qualidade de própolis. Mensagem Doce, n. 52, p.13-14, 1999. BANKOVA, V., KRASTEVA, G.B., POPOV, S. Seasonal variations of the chemical composition of brazilian propolis. Apidologie, v. 29, p. 361-367, 1998.

BIER, O. Técnicas bacteriológicas. In: BIER, O. Microbiologia e imunologia. 24. ed. São Paulo: Melhoramentos, 1985. Cap. 50, p. 919-998.

BONVEHI, J.S., COLL, F.V., JORDÁ, R.E. The composition, active components and bacteriostatic activity of propolis in dietetics. Journal of American Oil Chemists Society, v.71, n.5, p.529-532, 1994.

DeGRAVES, F.J., FETROW, J. Economics of mastitis and mastitis control. The Veterinary Clinics of North America: Food Animal Practice, v. 9, n. 3, p. 421-434, 1993.

DOBROWOLSKI, J.W., VOHORA, S.B., SHARMA, K. Antibacterial, antifungal, antiamoebic, antiinflammatory and antipyretic studies on propolis bee products. Journal of Ethnopharmacology, v. 35, n. 1, p. 77-82, 1991.

EVANS, J.B., KLOOS, W.E. Use of shake cultures in a semisolid thioglycolate medium for differentiating staphylococci from micrococci. Apllied Microbiology, v. 23, n. 2, p. 326-331, 1972.

FARIA, J.E. Prevenção e controle de infecção estafilocócica da glândula mamária pela vacinação e/ou antibioticoterapia associada ao dimetilsulfóxido (DMSO).Belo Horizonte, 1995. 101 p. Tese (Doutorado em Ciência Animal) - Universidade Federal de Minas Gerais, 1995.

FERNANDES Jr., A., LOPES, C.A.M., SFORCIN, J.M. Population analysis of susceptibility to propolis in reference strains of Staphylococcus aureuse Escherichia coli. Journal of Venomous Animals and Toxins, v. 3, n. 2, 1997.

GHISALBERTI, E.L. Propolis: a review. Bee World, v. 60, p. 59-84, 1979.

GIRAUDO, J.A., CALZOLARI, A., RAMPONE, H. Field trials of a vaccine against bovine mastitis. Evaluation in heifers. Journal of Dairy Science, v. 80, n. 5, p. 845-853, 1997.

GLINSKI, Z., MERESTA, T. Trials to standardize the antibacterial activity of propolis. Medycyna Weterynaryjna, v. 49. n. 1, p. 27-29, 1993.

GRANGE, J.M., DAVEY, R.W. Antibacterial properties of propolis (bee glue). Journal of the Royal Society of Medicine, v. 83, n. 3, p. 159-160, 1990.

HOLMBERG, O. Staphylococcus epidermidis isolated from bovine milk. Acta Veterinaria Scandinavia, p. 1-144, 1973. (Supplement, 45)

KOWALSKI, J.J. Microbial agents and bovine mastitis. Journal American Veterinary Medical Association, v. 170, n. 10, p. 1175-1177, 1977.

KUJUMGIEV, A., TSVETKOVA, I., SERKEDJIEVA, Y. Antibacterial, antifungal and antiviral activity of propolis of different geographic origin. Journal of Ethnopharmacology, v. 64, n. 3, p. 235-240, 1999. inibem acentuadamente o crescimento de Staphylococcus aureus. As concentrações de 0,3 e $0,43 \mathrm{mg} / \mathrm{mL}$ de extratos etanólicos de própolis são bactericidas para Streptococcus agalactiae.

LANGONI, H., DOMINGUES, P.F., FUNARI, S.R.C. Efeito antimicrobiano in vitro da propolis. In: CONGRESO IBEROLATINOAMERICANODE APICULTURA, 4., 1994, Rio Cuarto, Argentina, Anais... p. 189-192.

MARCUCCI, M.C. Propolis: chemical composition, biological properties and therapeutic activity. Apidologie, v. 26, n. 2, p. 83-99, 1995.

, NEGRI, G., CUNHA, I.B.S. Substâncias fenólicas em diferentes extratos de própolis, avaliadas por CLAE. In: REUNIÃO ANUAL DA SOCIEDADE BRASILEIRA DE QUÍMICA, 22., 1999, Poços de Caldas, MG. Livro de resumos... v.3; TC-031.

MERESTA, L., MERESTA, T. Sensitivity of bovine mastitis bacteria to propolis in vitro. Medycyna Weterynaryjna, v. 41, n. 8, p. 489-492, 1985. , BURDZINSKI, J. Treatment of mastitis in cows using an extract of propolis. Medycyna Weterynaryjna, v. 45, n. 7, p. 392-395, 1989.

MIROLYUBOV, M.G., BARSKOV, A.A. Propolis for bovine mastitis. Veterinariya, n. 2, p.. 45-46, 1980.

MIRZOEVA, O.K., GRISHANIN, R.N., CALDER, P.C. Antimicrobial action of propolis and some of its components: the effects on growth, membrane potencial and motility of bacteria. Microbiology Research, v. 152, n. 3, p. 239-246, 1997.

MIYATAKA, H., NISHIKI, M., MATSUMOTO, H. Evaluation of propolis. II. Effects of brazilian and chinese propolis on histamine release from rat peritoneal mast cells induced by compound $48 / 80$ and concanavalin $A$. Biological \& Pharmaceutical Bulletin, v. 21, n. 7, p. 723-729, 1998.

NATIONAL MASTITIS COUNCIL. Current concepts of bovine mastitis. 4. ed. Madison: The National Mastitis Council, 1998. 64 p.

. Microbiological procedures for the diagnosis of bovine mastitis. Washington. DC: University of New Hampshire Press, 1969. 27 p.

OBREGON, A.M., ROJAS, N. Antimicrobial action of alcoholic extracts of propolis. Revista Cubana de Farmacia, v. 24, n. 1, p. 34-44, 1990. PARK, Y.K., IKEGAKI, M., ABREU, J.A.S. Estudo da preparação dos extratos de própolis e suas aplicações. Ciência e Tecnologia de Alimentos, v. 18, n. 3, 1998.

QUINN, P.J., CARTER, M.E., MARKEY, B. Clinical veterinary microbiology. Spain: Wolfe, 1994. $648 \mathrm{p}$.

SCHALM, O.W., CARROL, E.J., JAIN, N.C. Bovine mastitis. Philadelphia: Lea e Febirger, 1971. $360 \mathrm{p}$.

SEIXAS, F.R.M.S., PEREIRA, A.S., RAMOS, M.F.S. Composição química da própolis brasileira das regiões sul e sudeste. In: REUNIÃO ANUAL DA SOCIEDADE BRASILEIRA DE QUÍMICA, 23., 2000, Poços de Caldas, MG. Livro de resumos... v. 2, PN-050.

TAKAISI-KIKUNI, N.B., SCHILCHER, H. Electron microscopic and microcalorimetric investigations of the possible mechanism of the antibacterial action of a defined propolis provenance. Planta Medica, v. 60, n. 3, p. 222-227, 1994.

WALKER, P., CRANE, E. Constituents of Propolis. Apidologie, v. 18, n. 4, p.327-334, 1987.

WOISKY, R.G., SALATINO, A. Analysis of propolis: some parameters and procedures for chemical quality control. Journal of Apicultural Research, v. 37, n. 2, p. 99-105, 1998. 